Article

\title{
Combined DNase and Proteinase Treatment Interferes with Composition and Structural Integrity of Multispecies Oral Biofilms
}

\author{
Lamprini Karygianni $(\mathbb{D}$, Thomas Attin and Thomas Thurnheer *(D) \\ Clinic of Conservative and Preventive Dentistry, Center of Dental Medicine, University of Zurich, 8032 Zurich, \\ Switzerland; Lamprini.Karygianni@zzm.uzh.ch (L.K.); Thomas.Attin@zzm.uzh.ch (T.A.) \\ * Correspondence: thomas.thurnheer@zzm.uzh.ch; Tel.: +41-44-6343376
}

Received: 28 February 2020; Accepted: 28 March 2020; Published: 1 April 2020

check for updates

\begin{abstract}
Modification of oral biofilms adhering to dental hard tissues could lead to new treatment approaches in cariology and periodontology. In this study the impact of DNase I and/or proteinase K on the formation of a simulated supragingival biofilm was investigated in vitro. Six-species biofilms were grown anaerobically in the presence of DNase I and proteinase K. After $64 \mathrm{~h}$ biofilms were either harvested and quantified by culture analysis or proceeded to staining followed by confocal laser scanning microscopy. Microbial cells were stained using DNA-dyes or fluorescent in situ hybridization. Exopolysaccharides, eDNA and exoproteins were stained with Calcofluor, anti-DNA-antibody, and Sypro $^{\mathrm{TM}}$ Ruby, respectively. Overall, results showed that neither DNase I nor proteinase K had an impact on total colony-forming units (CFUs) compared to the control without enzymes. However, DNase I significantly suppressed the growth of Actinomyces oris, Fusobacterium nucleatum, Streptococcus mutans, Streptococcus oralis and Candida albicans. Proteinase K treatment induced significant increase in $S$. mutans and S. oralis CFUs $(p<0.001)$, whereas $C$. albicans and $V$. dispar showed lower CFUs compared to the control. Interestingly, confocal images visualized the biofilm degradation caused by DNase I and proteinase K. Thus, enzymatic treatment should be combined with conventional antimicrobial agents aiming at both bactericidal effectiveness and biofilm dispersal.
\end{abstract}

Keywords: supragingival in vitro biofilm; extracellular polymeric substances (EPS); DNase I; proteinase K; CLSM; FISH

\section{Introduction}

Oral infectious diseases display the consequences of dynamic interactions between microorganisms, their host and the host's diet, leading to microbial colonization of oral surfaces and the establishment of pathogenic biofilms [1]. Biofilms formed on either tooth or dental material surfaces are known as oral biofilms and have been clearly recognized as a virulence factor in several oral infectious diseases, including dental caries, periodontitis and endodontic infections [2]. Biofilms are defined as "aggregates of micro-organisms in which the associated cells are frequently embedded in a self-produced matrix of extracellular polymeric substances (EPS) that are adherent to each other and/or a surface [3]. The EPS consists of exopolysaccharides, nucleic acids (eDNA, eRNA), proteins and lipids [3]. The composition and structure of EPS varies according to the host, presence of nutrients/substrates, type of microorganisms, and local mechanical factors e.g., shear stress [4]. The EPS promotes microbial adhesion on biotic and abiotic surfaces.

The most prominent EPS functions include adhesion, cohesion, scaffolding, mechanical stability, protection and dispersal [5]. These EPS can promote and strengthen cell adhesion to solid substrates, coaggregation and cohesion among different microbial cells, eventually leading to development of 
microcolonies [6]. Upon microbial attachment, EPS is produced and keeps microbial cells in close proximity enabling intercellular interactions within the biofilm mass [3]. The EPS matrix also constitutes a mechanically stable and complex chemical microenvironment that is substantial for the biofilm lifestyle [7]. Furthermore, EPS also increases biofilm resistance to diverse antimicrobials and host defenses $[8,9]$. In the meanwhile, it is clear that biofilms contain multi EPS-framed heterogeneous milieus able to alter local gene expression, metabolic activity and, importantly, intercellular signaling between distinct cell clusters or different species within the biofilm mass $[10,11]$. Finally, the EPS can act as a diffusion-limiting barrier against various antimicrobials resulting in limited drug access into the deeper layers of the biofilm, and thus, low antimicrobial effectiveness of cationic antimicrobials e.g., chlorhexidine (CHX) [12]. The fact that positively charged antimicrobial agents bind to negatively charged EPS components can lead to restricted penetration of molecules through biofilms, and thus enhance antimicrobial biofilm resistance [9], thereby allowing for the inactivation or degradation of disinfectants by matrix enzymes [13].

Over the years, several studies in the field of endodontology have provided an excellent source of information about the disinfection of root canals by solely eliminating pathogens [14-17]. However, the fundamental role of biofilm matrix to combat biofilm-related diseases has been overlooked so far. The need for the development of EPS-targeted antibiofilm therapies is crucial, since in several cases, biofilm infections do not respond to conventional antimicrobial treatment $[9,18]$. The integral role of eDNA in the establishment of mechanical stability within biofilms has been pointed out in recent reports [19-21]. The eDNA is either actively secreted or produced by controlled cell lysis, which is associated with microbial competition [22,23]. The ability of eDNA to promote microbial adhesion and coaggregation between microbes, including interspecies recognition [24,25], and to convey antimicrobial resistance [23] has been extensively explored so far. The importance of matrix proteins has been also underlined in several studies to date [26-28]. Enzymatic biofilm treatment with proteinase $\mathrm{K}$ has been applied to induce protein degradation in the matrix, thereby enhancing the discharge of nucleic acids [29]. By targeting eDNA, the enzyme DNase I has been also successfully utilized to assist the elimination of cystic fibrosis-related biofilms by antibiotics [30].

Modification of oral biofilms adhering to dental hard tissues could lead to new treatment approaches in cariology and periodontology. In this study, therefore, we focus on novel antibiofilm strategies including those targeting the vital structural and functional traits in EPS with emphasis on eDNA and proteins. The aim of this study was to assess the antibiofilm activity of two different concentrations of DNase I $(0.001 \mathrm{mg} / \mathrm{mL}, 0.002 \mathrm{mg} / \mathrm{mL})$, proteinase $\mathrm{K}(0.05 \mathrm{mg} / \mathrm{mL}, 0.1 \mathrm{mg} / \mathrm{mL})$ and combinations thereof against an in vitro simulated six-species supragingival biofilm upon constant enzymatic treatment over a period of $64 \mathrm{~h}$. In this study, confocal laser scanning microscopy (CLSM) was used to visualize the effects of enzymatic treatment with DNase I and proteinase K on the structural integrity and the composition of the treated biofilms. To our knowledge, structural and compositional alterations in multispecies biofilms following enzymatic treatment with DNase I, proteinase K or their combination has not been studied to date. The null hypothesis of this study is that neither DNase I nor proteinase $\mathrm{K}$ has an antibiofilm effect on multispecies biofilms in vitro.

\section{Materials and Methods}

\subsection{In Vitro Biofilm Experiments}

The procedures to produce six-species biofilms have been described in detail [31,32]. In brief, Actinomyces oris OMZ 745, Candida albicans OMZ 110, Fusobacterium nucleatum KP-F2 (OMZ 596), Streptococcus oralis SK 248 (OMZ 607), Streptococcus mutans UA159 (OMZ 918), and Veillonella dispar ATCC $17748^{\mathrm{T}}$ (OMZ 493) were used for biofilm formation. All strains were maintained on Columbia blood agar. Prior to the onset of biofilm experiments, all strains were transferred into modified fluid universal medium (mFUM) [33] and incubated under the same conditions anaerobically at $37^{\circ} \mathrm{C}$ for 
two cycles of precultures for $16 \mathrm{~h}$ and $8 \mathrm{~h}$, respectively. For the production of the inoculum all strains were adjusted to a defined optical density $\left(\mathrm{OD}_{550}=1.0\right)$ and mixed in equal volumes.

Biofilms were cultivated in 24-well polystyrene cell culture plates on sintered hydroxyapatite (HA; $\varnothing 9 \mathrm{~mm}$, Clarkson Chromatography Products, Inc., South Williams-port, PA 17702, USA) that had been preconditioned for pellicle formation in whole unstimulated pooled saliva (in the following termed saliva) for $4 \mathrm{~h}$. The processing of batches of saliva has been described in detail by Guggenheim et al. [33]. The growth medium contained $70 \%$ saliva, $30 \% \mathrm{mFUM}$ supplemented with Sørensen's buffer (final pH $7.2)$ as well as DNase I $(0.001 \mathrm{mg} / \mathrm{mL}$ or $0.002 \mathrm{mg} / \mathrm{mL})$ or proteinase $\mathrm{K}(0.05 \mathrm{mg} / \mathrm{mL}$ or $0.10 \mathrm{mg} / \mathrm{mL})$ or a combination of DNase I + proteinase $\mathrm{K}(0.001 \mathrm{mg} / \mathrm{mL}+0.05 \mathrm{mg} / \mathrm{mL}$ or $0.002 \mathrm{mg} / \mathrm{mL}+0.10 \mathrm{mg} / \mathrm{mL}$, respectively). The concentrations of DNase I and proteinase $\mathrm{K}$ have been determined in preliminary experiments (unpublished data). Control experiments contained neither DNase I nor proteinase K. The carbohydrate concentration of $\mathrm{mFUM}$ was either $0.3 \%$ glucose ( 0 to $16 \mathrm{~h}$ of biofilm cultivation) or $0.15 \%$ glucose and $0.15 \%$ sucrose ( $16 \mathrm{~h}$ to $64 \mathrm{~h}$ ). To initiate a biofilm experiment, disks were covered with $1.6 \mathrm{~mL}$ of growth medium and $200 \mu \mathrm{L}$ of inoculum. The medium was changed after $16 \mathrm{~h}$ and $40 \mathrm{~h}$. In order to remove non-adherent microorganisms, biofilms were dipped three times in saline after $16 \mathrm{~h}$, $20 \mathrm{~h}$ and $24 \mathrm{~h}$ as well as after $40 \mathrm{~h}, 44 \mathrm{~h}$ and $48 \mathrm{~h}$. After $64 \mathrm{~h}$ of biofilm growth, biofilms were either harvested for culture analyses by vigorous vortexing in $1 \mathrm{~mL}$ of $0.9 \% \mathrm{NaCl}$ or proceeded to staining and CLSM (see below).

For culture analyses, the hydroxyapatite disks were vortexed vigorously for $1 \mathrm{~min}$ in $1 \mathrm{~mL}$ of $0.9 \% \mathrm{NaCl}$ to harvest the adherent biofilms. After vortexing the harvested biofilms were sonicated at $30 \mathrm{~W}$ for $5 \mathrm{~s}$ (Sonifier B-12, Branson Ultrasonic, Urdorf, Switzerland) to ensure that the bacteria were dispersed. The resulting bacterial suspensions were serially diluted in $0.9 \% \mathrm{NaCl}$ Of each serial dilution, $50-\mu \mathrm{L}$ aliquots were plated on Columbia blood agar (CBA) base (Oxoid Ltd., Basingstoke, UK) supplemented with $5 \%$ whole human blood to estimate total colony-forming units (CFUs). To determine the species-specific bacterial numbers, selective agars were used to determine the CFUs for the species of the biofilms as described earlier [33,34]. In brief, CBA plates were used to obtain total bacterial counts and to enumerate $A$. oris and $V$. dispar; differential counting of $S$. mutans and S. oralis was accomplished with the use of Mitis Salivarius Agar (Difco Laboratories, Inc., Detroit, MI) supplemented with $0.001 \%(w / v)$ sodium tellurite, whereas selective growth of F. nucleatum was achieved with Fastidious Anaerobe Agar (Chemie Brunschwig, Basel, Switzerland) and BIGGY Agar (BBL, Becton Dickinson, Allschwil, Switzerland) was used to enumerate C. albicans. Agar plates were incubated at $37^{\circ} \mathrm{C}$ for $72 \mathrm{~h}$. Species identification was achieved by observation of colony morphology.

\subsection{Staining of Biofilms}

Prior to staining, biofilms were fixed in $1 \mathrm{~mL}$ of $4 \%$ paraformaldehyde + RNase inhibitor (RNAi) for two hours at $4-8{ }^{\circ} \mathrm{C}$. After fixation, discs were washed in $500 \mu \mathrm{L} 0.9 \% \mathrm{NaCl}+\mathrm{RNase}$ Inhibitor and dabbed off on a paper towel. In order to permeabilize Gram-positive bacteria biofilms were pretreated with $1 \mathrm{mg} / \mathrm{mL}$ lysozyme solution (Sigma, Buchs, Switzerland; 70V000 U/mL) in $0.1 \mathrm{M}$ Tris- $\mathrm{HCl}$, pH 7.5, $5 \mathrm{mM}$ EDTA for $8 \mathrm{~min}$ at room temperature and rinsed with $0.9 \%$ saline.

Total DNA was stained with a mixture of $3 \mu \mathrm{M}$ YoPro 1 iodide (Invitrogen, Basel, Switzerland) and $15 \mu \mathrm{M}$ Sytox green (Invitrogen) in nanopure water for $30 \mathrm{~min}$ or with $0.5 \mu \mathrm{g} / \mathrm{mL}$ 4',6-diamidino-2-phenylindole (DAPI) (SERVA Electrophoresis GmbH, Heidelberg, Germany) in nanopure water for $5 \mathrm{~min}$ at room temperature in the dark. Streptococcus mutans and S. oralis cells were specifically stained using fluorescence in situ hybridization (FISH) following earlier described protocols $[35,36]$. In brief, prehybridization $\left(15 \mathrm{~min}, 46^{\circ} \mathrm{C}\right)$ was performed in $500 \mu \mathrm{L}$ hybridization buffer with $25 \%$ formamide in the absence of any oligonucleotide probes. Thereafter, $500 \mu \mathrm{L}$ of hybridization buffer (25\% formamide) was used for each biofilm, supplemented with the species-specific fluorescein isothiocyanate (FITC)-labeled probe MIT447 (5'-CACYCGTTCTTCTCTTACA-3') and Cy3-labeled probe MUT590 (5'-ACTCCAGACTTTCCTGAC-3') to stain S. oralis and S. mutans, respectively, at a concentration of $20 \mathrm{ng} / \mu \mathrm{L}$. The incubation time for the hybridization was at least $3 \mathrm{~h}$ at $46^{\circ} \mathrm{C}$ in the 
dark. After the incubation, biofilms were transferred into washing buffer preheated to $48{ }^{\circ} \mathrm{C}$ and incubated for $20 \mathrm{~min}$ at this temperature.

The biofilm matrix was stained after FISH. Extracellular polysaccharides were stained by incubating biofilms with Calcofluor (Sigma; $10 \mu \mathrm{g} / \mathrm{mL}$ solution in $10 \mathrm{mM}$ sodium phosphate, pH 7.5) for $30 \mathrm{~min}$ at room temperature in the dark. Extracellular DNA (eDNA) was stained with Cy3-streptavidin labelled anti-DNA-antibody (Sigma-Aldrich, Buchs, Switzerland) according to the manufacturer's recommendations, and extracellular proteins were stained with Sypro ${ }^{\mathrm{TM}}$ Ruby according to the manufacturer's protocols.

After staining, the samples were embedded upside down on chamber slides in $100 \mu \mathrm{L}$ of Mowiol [37].

\subsection{Confocal Laser Scanning Microscopy (CLSM)}

CLSM was conducted using a Leica TCS SP5 microscope (Leica Microsystems, Wetzlar, Germany) provided by the Centre for Microscopy and Image Analysis of the University of Zurich. For the imaging of the biofilms on hydroxyapatite, the slightly modified procedure as described before [38], was performed. Briefly, the used lasers were an ultraviolet (UV) laser at $405 \mathrm{~nm}$ excitation, an Argon laser at $488 \mathrm{~nm}$ excitation, a diode pumped solid state (DPSS) diode laser at $561 \mathrm{~nm}$, and a helium-neon laser at $633 \mathrm{~nm}$ excitation. Furthermore, filters were adjusted at $430-470 \mathrm{~nm}$ to detect DAPI, at $500-540 \mathrm{~nm}$ for Yo Pro 1/Sytox green and FITC, at 570-600 nm for Cy3, and at 660-710 nm for Sypro ${ }^{\mathrm{TM}}$ Ruby. Biofilms were scanned sequentially in steps of $1 \mu \mathrm{m}$ thickness. Finally, the images were processed using Imaris 8.3 (Bitplane, Zurich, Switzerland).

\subsection{Statistical Analysis}

Three individual experiments were performed and each group represented in triplicate biofilm cultures per experiment. As a result, statistical analysis was performed on nine individual data points, coming from the nine individual biofilm cultures per experimental group. Two-way analysis of variance (ANOVA) was used to analyze the difference in bacterial cells per biofilm between the control group (standard nine-species biofilm) and the six additions of endodontic strains. Tukey's multiple comparisons test was used for correction. Missing values were ascribed the lowest detection limit value of the assay to allow for logarithmic transformation. Statistics have been implemented using GraphPad Prism (version 7) with the intent of comparing the species' total cell counts within the different biofilm formations (significance level $p<0.05$ ).

\section{Results}

\subsection{DNase I Significantly Suppressed the Growth of A. oris, F. nucleatum, S. mutans, S. oralis and C. albicans}

Figure $1 \mathrm{~A}$ shows the effects of DNase I on the $\log _{10}$ counts of six-species supragingival biofilms grown over $64 \mathrm{~h}$ in vitro. No significant differences could be found in regard with the effects of the low $(0.001 \mathrm{mg} / \mathrm{mL})$ versus high $(0.002 \mathrm{mg} / \mathrm{mL})$ tested DNase I concentration. Constant incubation of the biofilms with two different concentrations of DNase I $(0.001 \mathrm{mg} / \mathrm{mL}, 0.002 \mathrm{mg} / \mathrm{mL})$ had also no effect on the total bacterial counts. However, the $\log _{10}$ counts of five individual microbial species decreased significantly in a dose-independent manner after DNase I treatment. In particular, A. oris exhibited means of $6.45 \pm 0.27$ CFU $(0.001 \mathrm{mg} / \mathrm{mL}$ DNase I, $p=0.002)$ and $6.58 \pm 0.26 \mathrm{CFU}(0.002 \mathrm{mg} / \mathrm{mL}$ DNase $\mathrm{I}, p=0.026)$ in the $\log _{10}$ scale, which is a slightly, yet significantly reduced microbial growth compared with the untreated negative control (mean, $6.99 \pm 0.36)$. The counts of $F$. nucleatum $(0.001 \mathrm{mg} / \mathrm{mL}$ DNase I, $7.71 \pm 0.12 \log _{10}$ CFU, $p=0.002 ; 0.002 \mathrm{mg} / \mathrm{mL}$ DNase I, $7.58 \pm 0.25 \log _{10}$ CFU, $p=0.0001$ ) and C. albicans $\left(0.001 \mathrm{mg} / \mathrm{mL}\right.$ DNase I, $2.35 \pm 0.72 \log _{10}$ CFU, $p=0.0001 ; 0.002 \mathrm{mg} / \mathrm{mL}$ DNase I, $2.19 \pm 0.62$ $\log _{10}$ CFU, $p=0.0001$ ) also decreased after DNase I treatment compared to the negative control. Finally, treatment with DNase I had a negative impact on the streptococcal growth of $S$. mutans $(0.001 \mathrm{mg} / \mathrm{mL}$ DNase I, $6.37 \pm 0.23 \log _{10}$ CFU, $p=0.005 ; 0.002 \mathrm{mg} / \mathrm{mL}$ DNase I, $6.36 \pm 0.31 \log _{10} \mathrm{CFU}, p=0.004$ ) and 
S. oralis $\left(0.001 \mathrm{mg} / \mathrm{mL}\right.$ DNase I, $6.38 \pm 0.37 \log _{10}$ CFU, $p=0.0001 ; 0.002 \mathrm{mg} / \mathrm{mL}$ DNase I, $6.30 \pm 0.29$ $\log _{10} \mathrm{CFU}, p=0.0001$ ) as compared to the streptococci in the untreated biofilms.
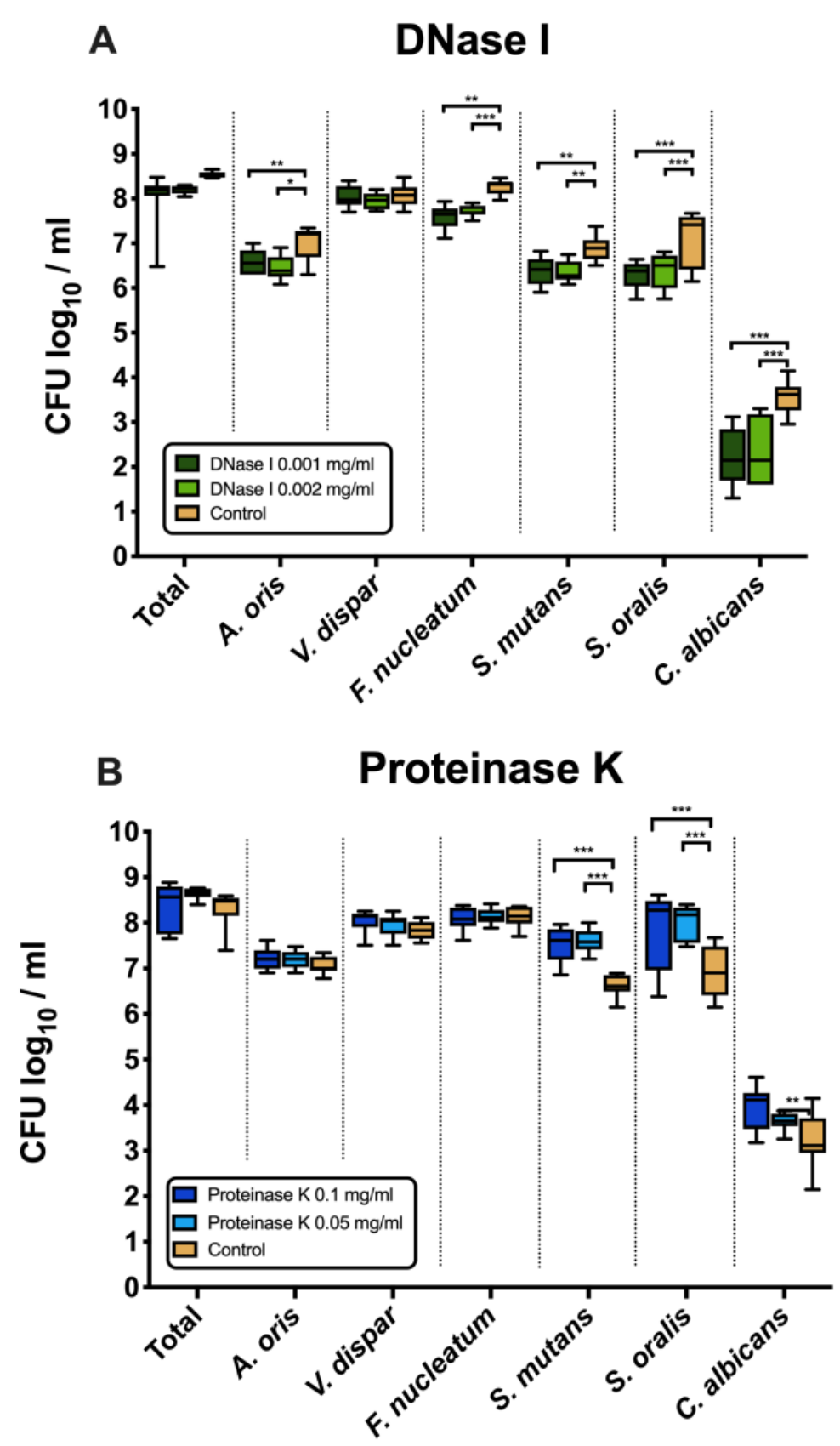

Figure 1. Box plots depicting the colony-forming units (CFUs) of six-species oral biofilms after exposure to DNase I $(0.001 \mathrm{mg} / \mathrm{mL}, 0.002 \mathrm{mg} / \mathrm{mL})(\mathbf{A})$ or proteinase $\mathrm{K}(0.05 \mathrm{mg} / \mathrm{mL}, 0.1 \mathrm{mg} / \mathrm{mL})(\mathbf{B})$, respectively. Untreated biofilms were also tested as negative controls. The CFUs are shown on a $\log _{10}$ scale per millilitre $\left(\log _{10} / \mathrm{mL}\right)$. Statistically significant differences are indicated with asterisks $\left({ }^{*} p<0.030\right.$, ** $\left.p<0.006,{ }^{* * *} p<0.0001\right)$.

\subsection{Counts of S. mutans, S. oralis and C. albicans Increased after Treatment with Proteinase $K$}

Figure 1B displays the microbial growth rates of in vitro six-species supragingival biofilms incubated for $64 \mathrm{~h}$ with two different concentrations of proteinase $\mathrm{K}(0.05 \mathrm{mg} / \mathrm{mL}, 0.1 \mathrm{mg} / \mathrm{mL})$.

Independent of the tested proteinase $\mathrm{K}$ concentration, all proteinase K-treated biofilms showed microbial growth comparable to that of the negative control. Nevertheless, the $\log _{10}$ counts of 
three individual microbial species increased substantially after biofilm treatment with proteinase $\mathrm{K}$. Specifically, both treatments with $0.05 \mathrm{mg} / \mathrm{mL}$ (mean, $7.59 \pm 0.25 \log _{10} \mathrm{CFU} ; p=0.0001$ ) and $0.1 \mathrm{mg} / \mathrm{mL}$ proteinase $\mathrm{K}$ (mean, $7.52 \pm 0.40 \log _{10} \mathrm{CFU} ; p=0.0001$ ) yielded a low, yet significant $\log _{10} \mathrm{CFU}$ increase in S. mutans counts compared with the untreated negative control (mean, $6.62 \pm 0.23 \log _{10} \mathrm{CFU}$ ). Similarly, a mild elevation of $S$. oralis $\log _{10}$ CFU counts was induced after biofilm incubation in $0.05 \mathrm{mg} / \mathrm{mL}$ (mean, $8.02 \pm 0.38 \log _{10} \mathrm{CFU} ; p=0.0001$ ) and $0.1 \mathrm{mg} / \mathrm{mL}$ proteinase $\mathrm{K}$ (mean, $7.84 \pm 0.88$ $\log _{10}$ CFU; $p=0.0001$ ) as compared to the untreated biofilms (mean, $6.94 \pm 0.55 \log _{10}$ CFU). Finally, the low proteinase $\mathrm{K}$ concentration of $0.1 \mathrm{mg} / \mathrm{mL}$ (mean, $3.64 \pm 0.19 \log _{10} \mathrm{CFU} ; p=0.0003$ ) yield a minor increase in the $\log _{10} \mathrm{CFU}$ counts of $C$. albicans compared with the negative control (mean, $3.25 \pm 0.59$ $\left.\log _{10} \mathrm{CFU}\right)$.

\subsection{Combined Treatment with DNase I and Proteinase K Induced a Significant Increase in Total Bacterial, S. mutans, and S. oralis Counts}

Figure 2 demonstrates the impact of the combined treatment with DNase I and proteinase $\mathrm{K}$ on the $\log _{10}$ counts of six-species supragingival biofilms grown over $64 \mathrm{~h}$ in vitro. The application of $0.001 \mathrm{mg} / \mathrm{mL}$ DNase I and $0.05 \mathrm{mg} / \mathrm{mL}$ proteinase $\mathrm{K}$ (mean, $8.52 \pm 0.14 \log _{10} \mathrm{CFU} ; p=0.0124$ ) or $0.002 \mathrm{mg} / \mathrm{mL}$ DNase I and $0.1 \mathrm{mg} / \mathrm{mL}$ proteinase $\mathrm{K}$ (mean, $8.58 \pm 0.13 \log _{10} \mathrm{CFU} ; p=0.0003$ ) had a low, yet significant effect on total microbial counts compared to the negative controls (mean, $7.95 \pm$ $0.16 \log _{10}$ CFU). Treatment with $0.001 \mathrm{mg} / \mathrm{mL}$ DNase I and $0.05 \mathrm{mg} / \mathrm{mL}$ proteinase $\mathrm{K}$ (mean, $7.52 \pm$ $0.09 \log _{10} \mathrm{CFU} ; p=0.0134$ ) or $0.002 \mathrm{mg} / \mathrm{mL}$ DNase I and $0.1 \mathrm{mg} / \mathrm{mL}$ proteinase $\mathrm{K}$ (mean, $7.76 \pm 0.11$ $\log _{10} \mathrm{CFU} ; p=0.0002$ ) had a positive impact on the streptococcal growth of $S$. mutans as compared to the untreated biofilms. Accordingly, a mild, yet significant increase of $S$. oralis $\log _{10}$ CFU counts was induced after biofilm incubation in $0.001 \mathrm{mg} / \mathrm{mL}$ DNase I and $0.05 \mathrm{mg} / \mathrm{mL}$ proteinase $\mathrm{K}$ (mean, $8.17 \pm$ $0.34 \log _{10} \mathrm{CFU} ; p=0.0001$ ) or $0.002 \mathrm{mg} / \mathrm{mL}$ DNase I and $0.1 \mathrm{mg} / \mathrm{mL}$ proteinase $\mathrm{K}$ (mean, $8.32 \pm 0.22$ $\log _{10} \mathrm{CFU} ; p=0.0001$ ) as compared to the untreated biofilms (mean, $6.84 \pm 0.87 \log _{10} \mathrm{CFU}$ ).

\section{DNase I and Proteinase K}

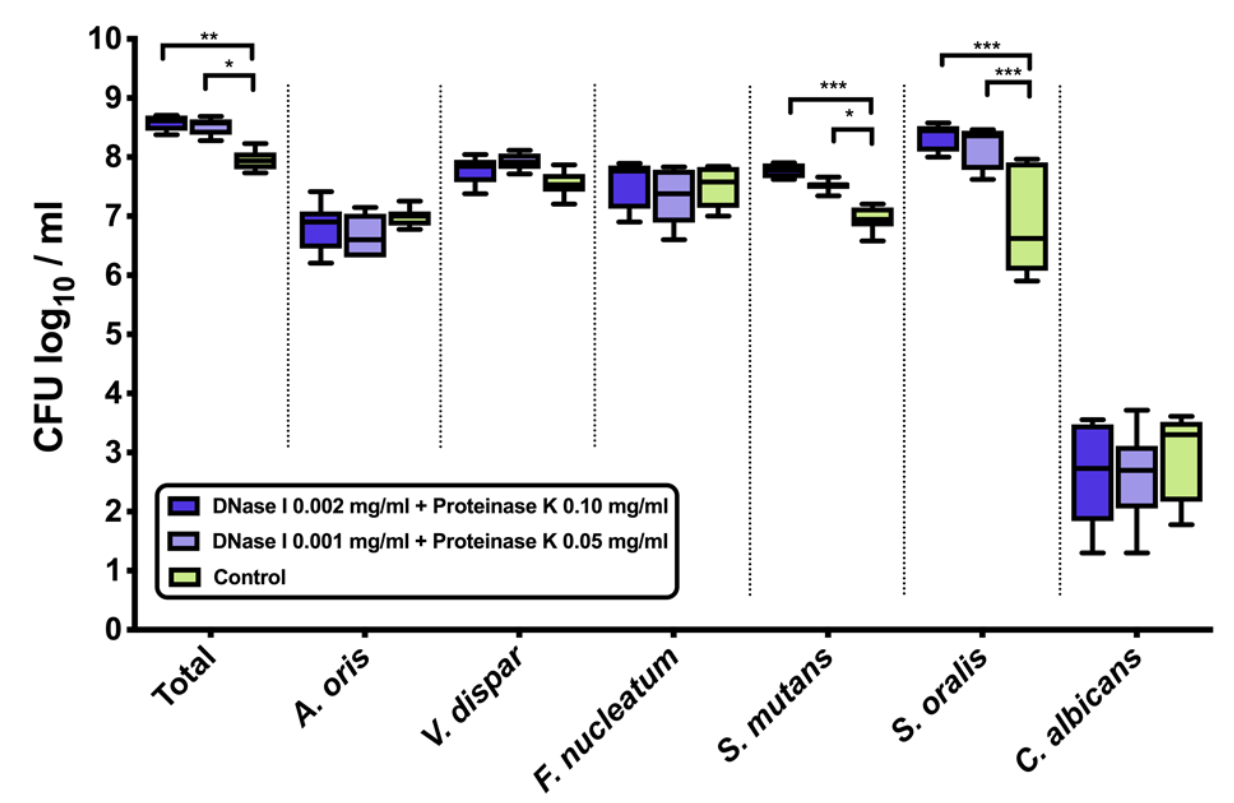

Figure 2. Box plots depicting the colony-forming units (CFUs) of six-species oral biofilms after simultaneous exposure to DNase I $(0.001 \mathrm{mg} / \mathrm{mL}, 0.002 \mathrm{mg} / \mathrm{mL})$ and proteinase $\mathrm{K}(0.05 \mathrm{mg} / \mathrm{mL}$, $0.1 \mathrm{mg} / \mathrm{mL}$ ). Untreated biofilms were also tested as negative controls. The CFUs are shown on a $\log _{10}$ scale per millilitre $\left(\log _{10} / \mathrm{mL}\right)$. Statistically significant differences are indicated with asterisks (* $p<0.030,{ }^{* *} p<0.006$, *** $\left.p<0.0001\right)$. 


\subsection{Combined Treatment with DNase I and Proteinase K Affected the Structural Integrity and Spatial Distribution of Biofilms}

The effects of DNase I and proteinase $\mathrm{K}$ treatment of the in vitro biofilms is shown in representative CLSM images in Figure 3. In the left column the effects with low concentrated DNase I and proteinase $\mathrm{K}(0.001 \mathrm{mg} / \mathrm{mL}$ and $0.05 \mathrm{mg} / \mathrm{mL}$, respectively) are shown, the right column shows the effects with high concentrated DNase I and proteinase $\mathrm{K}(0.002 \mathrm{mg} / \mathrm{mL}+0.10 \mathrm{mg} / \mathrm{mL}$, respectively). Biofilm organisms are stained green, extracellular polysaccharides appear blue, eDNA is stained red and extracellular proteins yellow. In the untreated biofilms (control; Figure 3A,B), eDNA and extracellular proteins could be observed throughout the whole biofilm. Remarkably, eDNA and extracellular proteins seemed to form small or even large aggregates. In DNase I treated biofilms (Figure 3C,D), eDNA could only be observed in the biofilm treated with low concentrated DNase I (Figure 3C) but not in the biofilm treated with high concentrated DNase (Figure 3D), whereas extracellular proteins could be seen in both biofilms. Although no quantification was performed, both biofilms treated with proteinase K (Figure 3E,F) showed fewer extracellular proteins but contrary to DNase I treatment, where all eDNA seemed to be degraded, even high concentrated proteinase was not able to break down all extracellular proteins. However, proteinase $\mathrm{K}$ treatment resulted in less dense biofilms compared to the control. The combined action of DNase I and proteinase K (Figure 3G,H) again showed less eDNA and only a few remaining extracellular proteins (although no quantification was performed) but most notably the structural integrity of the biofilms was affected, especially in the biofilm treated with high concentrated DNase I and proteinase $\mathrm{K}$ which can be observed in Figure $3 \mathrm{H}$. Compared to the control biofilm, the density and spatial distribution of the cells and extracellular matrix was substantially reduced and although no extracellular polysaccharide-degrading enzymes had been applied, the extracellular polysaccharides strongly decreased, too (Figure 3G,H).

\subsection{Fluorescence In Situ Hybridization (FISH)/CLSM Images Highlighted the Dominance of Streptococci after Combined Treatment with DNase I and Proteinase K}

Figure 4 shows FISH-stained biofilms. Total cells appear blue due to DAPI staining, S. mutans is stained red, S. oralis green and extracellular proteins are stained yellow. Figure $4 \mathrm{~A}$ depicts the untreated biofilm. The combined action of the effects with low concentrated DNase I and proteinase $\mathrm{K}(0.001 \mathrm{mg} / \mathrm{mL}$ and $0.05 \mathrm{mg} / \mathrm{mL}$, respectively) are shown in Figure $4 \mathrm{~B}$, and the effects with high concentrated DNase I and proteinase $\mathrm{K}(0.002 \mathrm{mg} / \mathrm{mL}+0.10 \mathrm{mg} / \mathrm{mL}$, respectively) are shown in Figure 4C. It is evident in particular that the combined action of high concentrated DNase I and proteinase $\mathrm{K}$ affected the numbers of streptococci, as in Figure 4C an increase in S. oralis cells is evident. Again, the enzyme-treated biofilms appeared less dense and seemed to have lost structural integrity. 

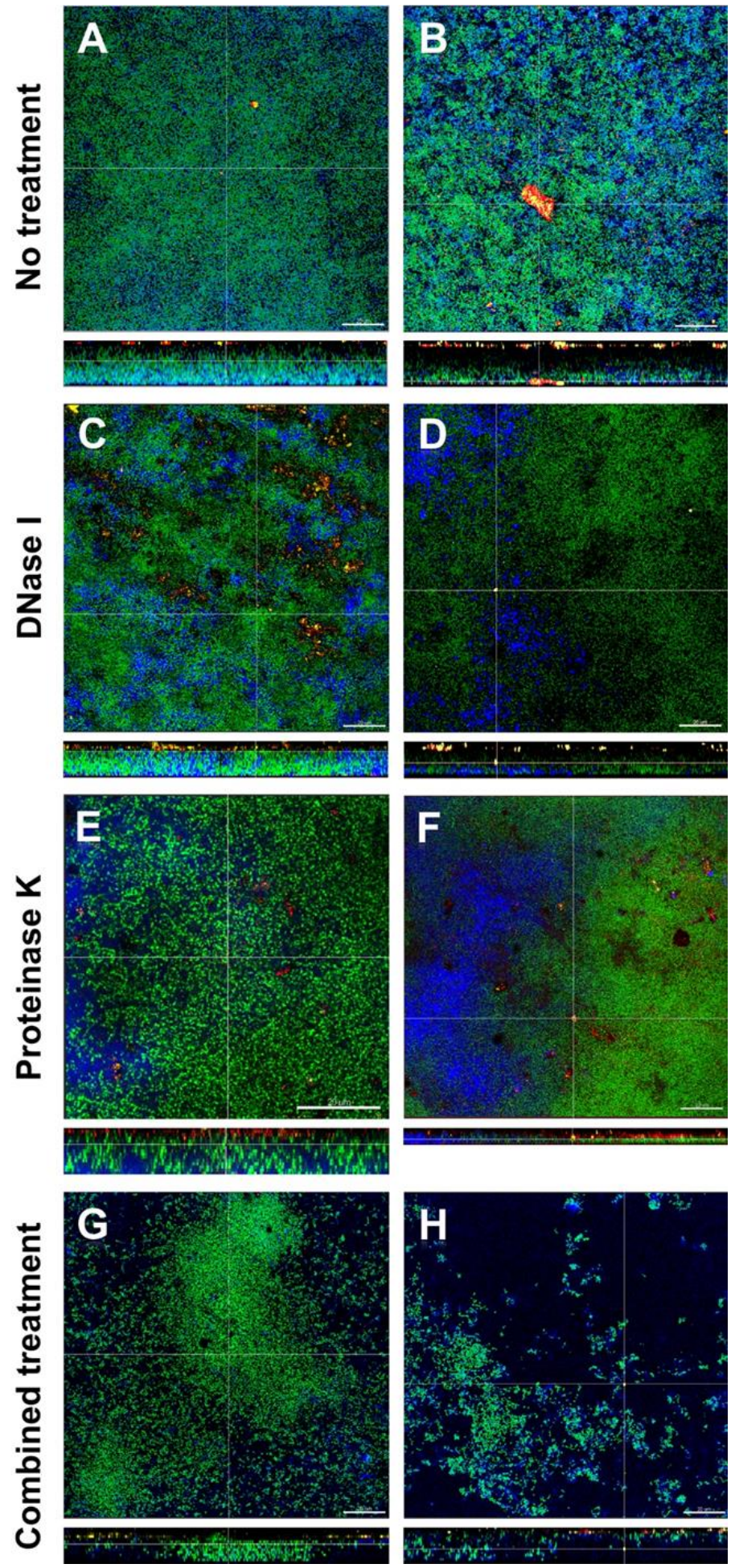

Figure 3. Representative confocal laser scanning microscopy (CLSM) images of six-species oral biofilms after no treatment (A,B), or exposure to $0.001 \mathrm{mg} / \mathrm{mL}$ DNase I (C), $0.002 \mathrm{mg} / \mathrm{mL}$ DNase I (D), $0.05 \mathrm{mg} / \mathrm{mL}$ proteinase $\mathrm{K}(\mathbf{E}), 0.1 \mathrm{mg} / \mathrm{mL}$ proteinase $\mathrm{K} 0.1 \mathrm{mg} / \mathrm{mL}(\mathbf{F})$, or combined treatment with $0.001 \mathrm{mg} / \mathrm{mL}$ DNase I and $0.05 \mathrm{mg} / \mathrm{mL}$ proteinase K (G), or with $0.002 \mathrm{mg} / \mathrm{mL}$ DNase I and $0.1 \mathrm{mg} / \mathrm{mL}$ proteinase $\mathrm{K}$ (H), respectively. Bacteria appear green due to DNA-staining with Yo Pro 1/Sytox Green; extracellular polysaccharides are stained blue with calcofluor; extracellular DNA appear red after staining with anti-DNA antibodies and streptavidin (Cy3); extracellular proteins appear yellow due to Sypro ${ }^{\mathrm{TM}}$ Ruby. The biofilm base in the cross sections is directed towards the top view. Scale $=20 \mu \mathrm{m}$. 

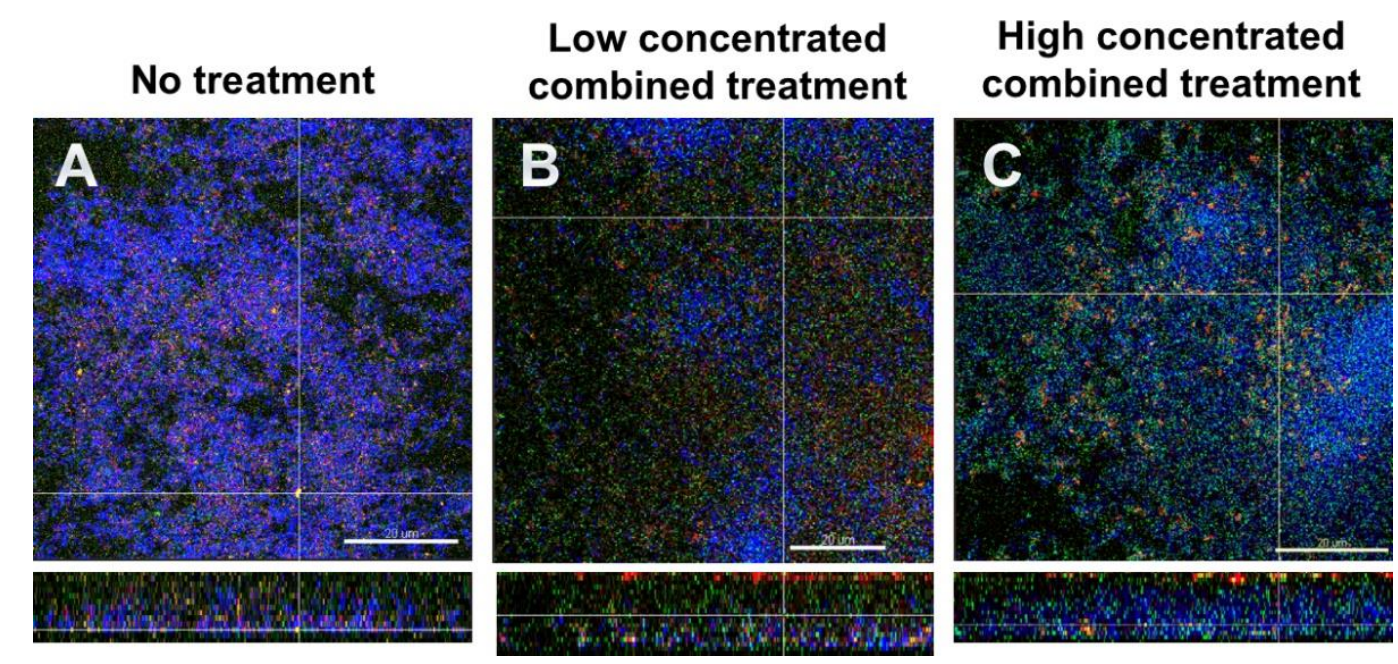

Figure 4. Representative CLSM images of six-species oral biofilms after no treatment (A), or combined treatment with $0.001 \mathrm{mg} / \mathrm{mL}$ DNase I and $0.05 \mathrm{mg} / \mathrm{mL}$ proteinase $\mathrm{K}(\mathbf{B})$, or with $0.002 \mathrm{mg} / \mathrm{mL}$ DNase I and $0.1 \mathrm{mg} / \mathrm{mL}$ proteinase $\mathrm{K}(\mathrm{C})$, respectively. After fluorescence in situ hybridization (FISH), microbial DNA appears blue due to DNA-staining with 4',6-diamidino-2-phenylindole (DAPI); S. oralis is stained green with MIT447- fluorescein isothiocyanate (FITC); S. mutans appears red after staining with MUT590-Cy3; extracellular proteins appear yellow due to Sypro ${ }^{\mathrm{TM}}$ Ruby. The biofilm base in the cross sections is directed towards the top view. Scale $=20 \mu \mathrm{m}$.

\section{Discussion}

The present study attempted for the first time to establish an effective method for enzymatic inhibition of in vitro multispecies oral biofilm growth using DNase I, proteinase $\mathrm{K}$ or their combinations. Although no decrease of the total bacterial counts was detected after constant incubation of the biofilms with two different concentrations of DNase I $(0.001 \mathrm{mg} / \mathrm{mL}, 0.002 \mathrm{mg} / \mathrm{mL})$ or proteinase $\mathrm{K}(0.05 \mathrm{mg} / \mathrm{mL}$, $0.1 \mathrm{mg} / \mathrm{mL}$ ), the application of combined enzymatic therapy with DNase I and proteinase K resulted in a slight decrease of the total microbial counts compared to the negative controls. In general, all enzymatic treatment protocols resulted in the shift of the microbial composition within the multispecies biofilms. In particular, treatment with DNase I resulted in the decrease of facultative and obligate anaerobic microorganisms, while the application of proteinase $\mathrm{K}$ mainly promoted streptococcal growth. Most importantly, biofilm visualization by CLSM revealed the degradation of the matrix, which led to the loss of structural integrity and alteration of spatial distribution of biofilms after combined treatment with DNase I and proteinase K. The combined enzymatic treatment not only induced biofilm degradation, it also favored the growth of streptococci probably by reducing nutritional competition. The innovative contribution of this study is that, to the best of our knowledge, the enzymatic inhibition of multispecies oral biofilm growth in vitro is here studied for the first time in combination with DNase I and proteinase $\mathrm{K}$. The null hypothesis of this study was rejected.

To study the bacterial colonization of tooth surfaces, hydroxyapatite slabs served as a representative substratum model with comparable physicochemical properties with that of human enamel. Another advantage of hydroxyapatite slabs is that they can be easily obtainable in large quantities. Other artificial tooth surfaces were avoided due to the alterations in biofilm composition when compared with biofilms attached to natural substrata [39]. The bacterial growth after the enzymatic treatment with DNase I, proteinase K, or both was quantified by the determination of CFU on agar media, which not only constitutes a representative cultural approach for assessing the antibiofilm effectiveness of the enzymatic therapy protocols but is also the most widely used technique to estimate biofilm cell viability. Based on the universal dilution series approach used to quantify cells, this technique is available in every microbiological laboratory. However, this method presents serious drawbacks and limitations [40] as it is time-consuming and labor-intensive, sometimes requiring days to perform 
enough replicates to obtain reproducible results. Moreover, the fraction of detached live cells may not be representative of the initial biofilm population and a subpopulation of biofilm cells can be viable but non-culturable (VBNC) and would not be detected by the CFU approach. Furthermore, since the biofilm requires suspension, errors can occur due to bacterial clumping and, if antimicrobial treatment was used, carryover can occur. An important consideration for choosing the culture technique, especially when antimicrobial treatment is involved, is that only live cells, capable of forming a colony, are counted. The problems of clumping have been overcome by sonicating the suspensions to ensure that the microorganisms were dispersed, and extensive washing of the biofilms in saline helped to minimize the carryover. Alternative methods of biofilm quantification are real-time polymerase chain reaction (PCR) and flow cytometry. The latter has been used to quickly and accurately determine biofilms cell viability [41], and although it allows differentiating between total, dead and VBNC, flow cytometry is definitively more expensive than CFU counting and, moreover, it does not allow microorganisms to be discriminated at the species level. Real time PCR on the other hand has been tested in earlier studies [42]. Although live and dead cells are counted with this technique, a PCR-based method using propidium monoazide can be applied to exclude or even quantify dead cells in oral multispecies biofilms [43]. Therefore, we decided to use the culture method for quantification of the supragingival biofilm model as previously described by Guggenheim et al. [33]. As far as CLSM imaging is concerned, the fluorescence signals from the in vitro oral biofilms were not affected by the autofluorescence of hydroxyapatite, although an earlier study had reported contradictory outcomes [44].

To date, a plethora of antimicrobial strategies have been applied for biofilm dispersal in dental medicine, and especially in regard with root canal disinfection [14-17]. However, due to several limitations of antimicrobials e.g., low effectiveness against mature biofilms, chemical treatment protocols can be supplemented by enzymatic methods. Enzymes such as DNases and proteinases can allow for the degradation of EPS, and thereby provide access of antimicrobials to the deeper biofilm layers, which are typically colonized by the most resistant microbial cells $[45,46]$. Besides DNase II, and TREX1 (or DNase III), DNase I is the major serum endonuclease that degrades eDNA in the extracellular matrix [47], and been combined with antibiotics [48], or clinically applied to disperse P. aeruginosa biofilms in cystic fibrosis patients [49]. In our report, targeting the eDNA with DNase I in the multispecies biofilm matrix had no impact on the total bacterial counts, but altered the bacterial composition and, thus, the spatial distribution of the bacterial species within the biofilm (Figure 1A). This effect may be attributed eventually to the active role of eDNA in gene transfer, which is facilitated by the close proximity of the microbial cells within the biofilm [50]. The fact that DNase I affected the growth of A. oris, F. nucleatum, S. mutans, S. oralis and C. albicans negatively, could be related to the function of eDNA as a nutrient source for immobilized biofilm cells [51]. Since the formation of oral biofilms reflects the ecological balance between different microbes colonizing the same microenvironment, our study showed that DNase I treatment can disturb this balance and may, therefore, be relevant for some combined clinical applications against biofilms. Although quorum sensing in multispecies biofilms has not been thoroughly investigated yet, it is possible that a still unknown quorum-sensing mechanism triggers a compositional shift within the biofilms after DNase I treatment to anticipate for the mechanical instability caused by the absence of eDNA [52].

Since proteins belong together with polysaccharides to the main constituents of EPS, diverse proteases such as Spl protease, proteinase $\mathrm{K}$, and aureolysin seem to have high potential for matrix degradation, and thus, biofilm removal [53]. In previous studies, treatment with proteinase $\mathrm{K}$ induced a significant detachment of proteinaceous-rich in Bap proteins-Staphylococcus aureus biofilms [54,55]. Similarly, $200 \mu \mathrm{g} / \mathrm{mL}$ proteinase K triggered complete dispersal of Listeria monocytogenes biofilms in $5 \mathrm{~min}$ [56]. However, in another report, concentrations of proteinase $\mathrm{K}$ up to $32 \mu \mathrm{g} / \mathrm{mL}$ had no impact on planktonic growth of $S$. aureus cells [57]. In our study, despite the fact that constant treatment with proteinase $\mathrm{K}$ during biofilm formation for $64 \mathrm{~h}$ had no effect on total bacterial counts, it favored streptococcal growth of S. mutans and S. oralis (Figure 1B). This can be attributed to the fact that streptococci may not only need amino acids for biosynthetic processes to neutralize the acidity resulting 
from carbohydrate metabolism, but also as a nutrient source [58,59]. Another explanation for the proteinase K-mediated increase in streptococcal growth is that proteinase $\mathrm{K}$ presumably deactivates quorum-sensing- or competence-stimulating peptides, which may be involved in either streptococcal proliferation or interspecies competition within biofilms, respectively.

While the use of culture method allowed for the quantification of the microbial counts and the assessment of the microbial shift after the enzymatic inhibition of the biofilm growth, CLSM was used to examine the three-dimensional (3D) structure of biofilms. The combination with FISH and other staining procedures allows biofilm microorganisms to be stained specifically as well as the components of the biofilm matrix. To demonstrate the effects of DNase I and proteinase $\mathrm{K}$ on the structure of in vitro biofilms, we used DNA dyes such as Yo Pro 1/Sytox green or DAPI to stain the bulk of biofilm cells. The biofilm matrix components such as extracellular polysaccharides, eDNA, and extracellular proteins were stained with Calcofluor, Cy3-streptavidin labelled anti-DNA-antibody, and Sypro ${ }^{\mathrm{TM}}$ Ruby, respectively. The combined application of DNase I and proteinase K affected also the biofilm infrastructure, by inducing less compact biofilms compared to untreated biofilms. Whitchurch et al. [60] investigated the effect of DNase I on biofilm formation using a flow-chamber system. Their results using Pseudomonas aeruginosa biofilms showed that the presence of DNase I in the medium prevented biofilm formation and the authors suggested that DNase I treatment might be beneficial as an early prophylactic measure to prevent biofilm establishment. In our study biofilms were cultured in the presence of DNase I which resulted in an efficient removal of eDNA. However, this effect was not so prominent when DNase treatment was made after biofilm formation as seen in previous experiments. Similar results were reported by Yu et al. [61] when DNase was applied on E. faecalis biofilms in an in vitro root canal system. In the same study it was demonstrated that DNase treatment affected the microstructure of the biofilms. Also, compared to the control, the volume of exopolysaccharides in the DNase-treated biofilm was significantly lower in this endodontic biofilm model [61]. Our study showed similar results, however, the reduction of exopolysaccharides was more evident when biofilms were treated with DNase I and proteinase K (Figure 3H). Streptococcus pneumoniae clinical isolates showed evidence of eDNA as demonstrated by in situ staining of the matrix with the eDNA stain PicoGreen [62]. Treatment of these isolates with DNase I resulted in a dose-dependent reduction of the pneumococcal biofilm biomass as we observed also in our in vitro biofilms.

Niazi et al. [63] investigated the dynamics of biofilm killing and disruption using $1 \%$ trypsin and $1 \%$ proteinase $\mathrm{K}$ on an endodontic multispecies biofilm model. Confocal images of live-dead stained biofilms showed that trypsin and proteinase $\mathrm{K}$ were effective in killing bacteria, as the viable counts were significantly lower than in the negative control. In another study, the same authors examined the synergistic effect of a disinfection regimen consisting of trypsin and proteinase $\mathrm{K}$ in combination with chlorhexidine on an endodontic multispecies biofilm model. Chlorhexidine used in combination with trypsin and proteinase $\mathrm{K}$ enhanced the biofilm killing effect of the entire disinfection regime [64]. In our study, proteinase $\mathrm{K}$ was able to remove most of the extracellular proteins and the treatment resulted in less dense biofilms compared to the control biofilm. A synergistic effect could be observed, when proteinase K was combined with DNase I which affected also the structural integrity of the biofilms (Figure 3G,H). Ali Mohammed et al. [65] tested DNase I and proteinase K on Fusobacterium nucleatum and Porphyromonas gingivalis biofilms after $0 \mathrm{~h}$ and $48 \mathrm{~h}$ of growth. However, DNase I and proteinase K had little effect on the biofilm matrix in the conditions used. In a study by Lim et al. [66] Escherichia coli biofilms were treated with DNase I, proteinase K and sodium hypochlorite. When enzymes were added to the preformed biofilms on a stainless steel substrate, none of the DNase I, proteinase $\mathrm{K}$, or $\mathrm{NaClO}$ treatment alone significantly reduced the number of viable cells. However, the combined treatment using proteinase $\mathrm{K}$ followed by $\mathrm{NaClO}$, showed a notable reduction of viable cells [66]. The role of eDNA and exoproteins on biofilm formation were investigated by George and Halami [67] by treating mature Lactobacillus plantarum biofilms with DNase I and proteinase K. While untreated biofilms were observed to possess significantly dense population of both live and dead cells, a considerable decrease in the cell density was evident in DNase I-treated and proteinase K-treated biofilms. The 
authors concluded that the examined biofilms comprised eDNA and exoproteins and that these matrix components are vital constituents of biofilms [67]. In our study, the combined application of DNase I and proteinase K not only led to a loss of biofilm integrity, it also favored growth of streptococci (see Figure 4C) probably by reducing nutritional competition between the biofilm organisms. Enzymatic treatment of the biofilms seemed to help disrupting the bacteria from the biofilm matrix; it would be interesting to see, whether such DNase I and proteinase K treated biofilms favor synergistic effects with antimicrobial agents. This, however, remains to be elucidated in future studies.

It should be noted that neither DNase I nor proteinase $\mathrm{K}$ treatment had a negative impact on total bacterial counts. This implies that both enzymes interact only with eDNA and extracellular matrix proteins, without penetrating the intact membranes of the microbial cells, thereby interfering solely with the structural integrity of the biofilms. So, despite the fact that DNase I and proteinase K can degrade biofilms effectively, they should be combined with conventional antimicrobial agents aiming at both bactericidal effectiveness and biofilm dispersal.

Author Contributions: T.T. conceived the idea for this manuscript and was involved in study design as well as manuscript drafting; L.K. was involved in the data analysis and manuscript drafting; and T.A. was involved in data interpretation, and manuscript drafting. All authors have read and agreed to the published version of the manuscript.

Funding: The study was supported by Institutional funds of the University of Zurich.

Acknowledgments: We would like to thank Patricia Martín Pérez for the outstanding technical assistance during the experiments. We also thank the Center of Microscopy and Image Analysis (ZMB) of the University of Zurich for the supply of confocal laser scanning microscope (CLSM).

Conflicts of Interest: The authors declare no conflict of interest.

\section{References}

1. Marsh, P.D.; Zaura, E. Dental biofilm: Ecological interactions in health and disease. J. Clin. Periodontol. 2017, 44 (Suppl. 18), S12-S22. [CrossRef]

2. Mira, A.; Simon-Soro, A.; Curtis, M.A. Role of microbial communities in the pathogenesis of periodontal diseases and caries. J. Clin. Periodontol. 2017, 44 (Suppl. 18), S23-S38. [CrossRef]

3. Flemming, H.C.; Wingender, J.; Szewzyk, U.; Steinberg, P.; Rice, S.A.; Kjelleberg, S. Biofilms: An emergent form of bacterial life. Nat. Rev. Microbiol. 2016, 14, 563-575. [CrossRef] [PubMed]

4. Flemming, H.C. EPS-then and now. Microorganisms 2016, 4, 41. [CrossRef] [PubMed]

5. Flemming, H.C.; Wingender, J. Relevance of microbial extracellular polymeric substances (EPSs)-Part I: Structural and ecological aspects. Water Sci. Technol. A J. Int. Assoc. Water Pollut. Res. 2001, 43, 1-8. [CrossRef]

6. Peterson, B.W.; He, Y.; Ren, Y.; Zerdoum, A.; Libera, M.R.; Sharma, P.K.; van Winkelhoff, A.J.; Neut, D.; Stoodley, P.; van der Mei, H.C.; et al. Viscoelasticity of biofilms and their recalcitrance to mechanical and chemical challenges. FEMS Microbiol. Rev. 2015, 39, 234-245. [CrossRef] [PubMed]

7. Koo, H.; Yamada, K.M. Dynamic cell-matrix interactions modulate microbial biofilm and tissue 3D microenvironments. Curr. Opin. Cell Biol. 2016, 42, 102-112. [CrossRef]

8. Dragos, A.; Kovacs, A.T. The peculiar functions of the bacterial extracellular matrix. Trends Microbiol. 2017, 25, 257-266. [CrossRef]

9. Koo, H.; Allan, R.N.; Howlin, R.P.; Stoodley, P.; Hall-Stoodley, L. Targeting microbial biofilms: Current and prospective therapeutic strategies. Nat. Rev. Microbiol. 2017, 15, 740-755. [CrossRef]

10. LewisOscar, F.; Nithya, C.; Alharbi, S.A.; Alharbi, N.S.; Thajuddin, N. In vitro and in silico attenuation of quorum sensing mediated pathogenicity in Pseudomonas aeruginosa using Spirulina platensis. Microb. Pathog. 2018, 116, 246-256. [CrossRef]

11. Whiteley, M.; Diggle, S.P.; Greenberg, E.P. Progress in and promise of bacterial quorum sensing research. Nature 2017, 551, 313-320. [CrossRef] [PubMed]

12. Karygianni, L.; Ruf, S.; Follo, M.; Hellwig, E.; Bucher, M.; Anderson, A.C.; Vach, K.; Al-Ahmad, A. Novel broad-spectrum antimicrobial photoinactivation of in situ oral biofilms by visible light plus water-filtered infrared A. Appl. Environ. Microbiol. 2014, 80, 7324-7336. [CrossRef] [PubMed] 
13. Hall, C.W.; Mah, T.F. Molecular mechanisms of biofilm-based antibiotic resistance and tolerance in pathogenic bacteria. FEMS Microbiol. Rev. 2017, 41, 276-301. [CrossRef] [PubMed]

14. Goncalves, L.S.; Rodrigues, R.C.; Andrade Junior, C.V.; Soares, R.G.; Vettore, M.V. The effect of sodium hypochlorite and chlorhexidine as irrigant solutions for root canal disinfection: A systematic review of clinical trials. J. Endod. 2016, 42, 527-532. [CrossRef] [PubMed]

15. Zehnder, M. Root canal irrigants. J. Endod. 2006, 32, 389-398. [CrossRef] [PubMed]

16. Ballal, N.V.; Gandhi, P.; Shenoy, P.A.; Shenoy Belle, V.; Bhat, V.; Rechenberg, D.K.; Zehnder, M. Safety assessment of an etidronate in a sodium hypochlorite solution: Randomized double-blind trial. Int. Endod. J. 2019, 52, 1274-1282. [CrossRef] [PubMed]

17. Sasanakul, P.; Ampornaramveth, R.S.; Chivatxaranukul, P. Influence of adjuncts to irrigation in the disinfection of large root canals. J. Endod. 2019, 45, 332-337. [CrossRef] [PubMed]

18. Liu, Y.; Ren, Z.; Hwang, G.; Koo, H. Therapeutic strategies targeting cariogenic biofilm microenvironment. Adv. Dent. Res. 2018, 29, 86-92. [CrossRef]

19. DeFrancesco, A.S.; Masloboeva, N.; Syed, A.K.; DeLoughery, A.; Bradshaw, N.; Li, G.W.; Gilmore, M.S.; Walker, S.; Losick, R. Genome-wide screen for genes involved in eDNA release during biofilm formation by Staphylococcus aureus. Proc. Natl. Acad. Sci. USA 2017, 114, E5969-E5978. [CrossRef]

20. Florez Salamanca, E.J.; Klein, M.I. Extracellular matrix influence in Streptococcus mutans gene expression in a cariogenic biofilm. Mol. Oral Microbiol. 2018, 33, 181-193. [CrossRef]

21. Wang, S.; Liu, X.; Liu, H.; Zhang, L.; Guo, Y.; Yu, S.; Wozniak, D.J.; Ma, L.Z. The exopolysaccharide Psl-eDNA interaction enables the formation of a biofilm skeleton in Pseudomonas aeruginosa. Environ. Microbiol. Rep. 2015, 7, 330-340. [CrossRef]

22. Rainey, K.; Michalek, S.M.; Wen, Z.T.; Wu, H. Glycosyltransferase-mediated biofilm matrix dynamics and virulence of streptococcus mutans. Appl. Environ. Microbiol. 2019, 85, e02247-18. [CrossRef]

23. Okshevsky, M.; Meyer, R.L. The role of extracellular DNA in the establishment, maintenance and perpetuation of bacterial biofilms. Crit. Rev. Microbiol. 2015, 41, 341-352. [CrossRef]

24. Wright, C.J.; Burns, L.H.; Jack, A.A.; Back, C.R.; Dutton, L.C.; Nobbs, A.H.; Lamont, R.J.; Jenkinson, H.F. Microbial interactions in building of communities. Mol. Oral Microbiol. 2013, 28, 83-101. [CrossRef]

25. Das, T.; Sharma, P.K.; Busscher, H.J.; van der Mei, H.C.; Krom, B.P. Role of extracellular DNA in initial bacterial adhesion and surface aggregation. Appl. Environ. Microbiol. 2010, 76, 3405-3408. [CrossRef]

26. Taglialegna, A.; Lasa, I.; Valle, J. Amyloid structures as biofilm matrix scaffolds. J. Bacteriol. 2016, 198, 2579-2588. [CrossRef]

27. Taglialegna, A.; Navarro, S.; Ventura, S.; Garnett, J.A.; Matthews, S.; Penades, J.R.; Lasa, I.; Valle, J. Staphylococcal bap proteins build amyloid scaffold biofilm matrices in response to environmental signals. PLoS Pathog. 2016, 12, e1005711. [CrossRef]

28. Schwartz, K.; Ganesan, M.; Payne, D.E.; Solomon, M.J.; Boles, B.R. Extracellular DNA facilitates the formation of functional amyloids in Staphylococcus aureus biofilms. Mol. Microbiol. 2016, 99, 123-134. [CrossRef]

29. Wu, J.; Xi, C. Evaluation of different methods for extracting extracellular DNA from the biofilm matrix. Appl. Environ. Microbiol. 2009, 75, 5390-5395. [CrossRef]

30. Das, T.; Simone, M.; Ibugo, A.I.; Witting, P.K.; Manefield, M.; Manos, J. Glutathione enhances antibiotic efficiency and effectiveness of DNase I in disrupting pseudomonas aeruginosa biofilms while also inhibiting pyocyanin activity, thus facilitating restoration of cell enzymatic activity, confluence and viability. Front. Microbiol. 2017, 8, 2429. [CrossRef]

31. Shapiro, S.; Giertsen, E.; Guggenheim, B. An in vitro oral biofilm model for comparing the efficacy of antimicrobial mouthrinses. Caries Res. 2002, 36, 93-100. [CrossRef]

32. Thurnheer, T.; Gmür, R.; Shapiro, S.; Guggenheim, B. Mass transport of macromolecules within an in vitro model of supragingival plaque. Appl. Environ. Microbiol. 2003, 69, 1702-1709. [CrossRef]

33. Guggenheim, B.; Giertsen, E.; Schüpbach, P.; Shapiro, S. Validation of an in vitro biofilm model of supragingival plaque. J. Dent. Res. 2001, 80, 363-370. [CrossRef]

34. Klinke, T.; Guggenheim, B.; Klimm, W.; Thurnheer, T. Dental caries in rats associated with candida albicans. Caries Res. 2011, 45, 100-106. [CrossRef]

35. Thurnheer, T.; Gmür, R.; Guggenheim, B. Multiplex FISH analysis of a six-species bacterial biofilm. J. Microbiol. Meth. 2004, 56, 37-47. [CrossRef] 
36. Ammann, T.; Gmur, R.; Thurnheer, T. Advancement of the 10-species subgingival Zurich Biofilm model by examining different nutritional conditions and defining the structure of the in vitro biofilms. BMC Microbiol. 2012, 12, 227. [CrossRef]

37. Guggenheim, M.; Shapiro, S.; Gmür, R.; Guggenheim, B. Spatial arrangements and associative behavior of species in an in vitro oral biofilm model. Appl. Environ. Microbiol. 2001, 67, 1343-1350. [CrossRef]

38. Zehnder, M.; Rechenberg, D.; Thurnheer, T.; Lüthi-Schaller, H.; Belibasakis, G. FISHing for gutta-percha-adhered biofilms in purulent post-treatment apical periodontitis. Mol. Oral Microbiol. 2017, 32, 226-235. [CrossRef]

39. Teles, F.R.; Teles, R.P.; Sachdeo, A.; Uzel, N.G.; Song, X.Q.; Torresyap, G.; Singh, M.; Papas, A.; Haffajee, A.D.; Socransky, S.S. Comparison of microbial changes in early redeveloping biofilms on natural teeth and dentures. J. Periodontol. 2012, 83, 1139-1148. [CrossRef]

40. Li, L.; Mendis, N.; Trigui, H.; Oliver, J.D.; Faucher, S.P. The importance of the viable but non-culturable state in human bacterial pathogens. Front. Microbiol. 2014, 5, 258. [CrossRef]

41. Cerca, F.; Trigo, G.; Correia, A.; Cerca, N.; Azeredo, J.; Vilanova, M. SYBR green as a fluorescent probe to evaluate the biofilm physiological state of Staphylococcus epidermidis, using flow cytometry. Can. J. Microbiol. 2011, 57, 850-856. [CrossRef] [PubMed]

42. Ammann, T.W.; Bostanci, N.; Belibasakis, G.N.; Thurnheer, T. Validation of a quantitative real-time PCR assay and comparison with fluorescence microscopy and selective agar plate counting for species-specific quantification of an in vitro subgingival biofilm model. J. Periodontal Res. 2013, 48, 517-526. [CrossRef] [PubMed]

43. Alvarez, G.; Gonzalez, M.; Isabal, S.; Blanc, V.; Leon, R. Method to quantify live and dead cells in multi-species oral biofilm by real-time PCR with propidium monoazide. AMB Express 2013, 3, 1. [CrossRef]

44. Wood, S.R.; Kirkham, J.; Marsh, P.D.; Shore, R.C.; Nattress, B.; Robinson, C. Architecture of intact natural human plaque biofilms studied by confocal laser scanning microscopy. J. Dent. Res. 2000, 79, 21-27. [CrossRef]

45. Saggu, S.K.; Jha, G.; Mishra, P.C. Enzymatic Degradation of Biofilm by Metalloprotease From Microbacterium sp. SKS10. Front. Bioeng. Biotechnol. 2019, 7, 192. [CrossRef]

46. Fleming, D.; Rumbaugh, K.P. Approaches to Dispersing Medical Biofilms. Microorganisms 2017, 5, 15. [CrossRef]

47. Sharma, K.; Pagedar Singh, A. Antibiofilm Effect of DNase against Single and Mixed Species Biofilm. Foods 2018, 7, 42. [CrossRef]

48. Tetz, G.V.; Artemenko, N.K.; Tetz, V.V. Effect of DNase and antibiotics on biofilm characteristics. Antimicrob. Agents Chemother. 2009, 53, 1204-1209. [CrossRef]

49. Suri, R. The use of human deoxyribonuclease (rhDNase) in the management of cystic fibrosis. BioDrugs 2005, 19, 135-144. [CrossRef]

50. Li, Y.H.; Lau, P.C.; Lee, J.H.; Ellen, R.P.; Cvitkovitch, D.G. Natural genetic transformation of Streptococcus mutans growing in biofilms. J. Bacteriol. 2001, 183, 897-908. [CrossRef]

51. Brown, H.L.; Hanman, K.; Reuter, M.; Betts, R.P.; van Vliet, A.H. Campylobacter jejuni biofilms contain extracellular DNA and are sensitive to DNase I treatment. Front. Microbiol. 2015, 6, 699. [CrossRef] [PubMed]

52. Brackman, G.; Breyne, K.; De Rycke, R.; Vermote, A.; Van Nieuwerburgh, F.; Meyer, E.; Van Calenbergh, S.; Coenye, T. The Quorum Sensing Inhibitor Hamamelitannin Increases Antibiotic Susceptibility of Staphylococcus aureus Biofilms by Affecting Peptidoglycan Biosynthesis and eDNA Release. Sci. Rep. 2016, 6, 20321. [CrossRef] [PubMed]

53. Lister, J.L.; Horswill, A.R. Staphylococcus aureus biofilms: Recent developments in biofilm dispersal. Front. Cell. Infect. Microbiol. 2014, 4, 178. [CrossRef] [PubMed]

54. Gilan, I.; Sivan, A. Effect of proteases on biofilm formation of the plastic-degrading actinomycete Rhodococcus ruber C208. FEMS Microbiol. Lett. 2013, 342, 18-23. [CrossRef]

55. Kumar Shukla, S.; Rao, T.S. Dispersal of Bap-mediated Staphylococcus aureus biofilm by proteinase K. J. Antibiot. 2013, 66, 55-60. [CrossRef]

56. Nguyen, U.T.; Burrows, L.L. DNase I and proteinase K impair Listeria monocytogenes biofilm formation and induce dispersal of pre-existing biofilms. Int. J. Food Microbiol. 2014, 187, 26-32. [CrossRef]

57. Shukla, S.K.; Rao, T.S. Staphylococcus aureus biofilm removal by targeting biofilm-associated extracellular proteins. Indian J. Med. Res. 2017, 146, S1-S8. [CrossRef] 
58. Takahashi, N. Oral Microbiome Metabolism: From “Who Are They?" to "What Are They Doing?". J. Dent. Res. 2015, 94, 1628-1637. [CrossRef]

59. Willenborg, J.; Goethe, R. Metabolic traits of pathogenic streptococci. FEBS Lett. 2016, 590, 3905-3919. [CrossRef]

60. Whitchurch, C.B.; Tolker-Nielsen, T.; Ragas, P.C.; Mattick, J.S. Extracellular DNA required for bacterial biofilm formation. Science 2002, 295, 1487. [CrossRef]

61. Yu, M.K.; Kim, M.A.; Rosa, V.; Hwang, Y.C.; Del Fabbro, M.; Sohn, W.J.; Min, K.S. Role of extracellular DNA in Enterococcus faecalis biofilm formation and its susceptibility to sodium hypochlorite. J. Appl. Oral Sci. 2019, 27, e20180699. [CrossRef]

62. Hall-Stoodley, L.; Nistico, L.; Sambanthamoorthy, K.; Dice, B.; Nguyen, D.; Mershon, W.J.; Johnson, C.; Hu, F.Z.; Stoodley, P.; Ehrlich, G.D.; et al. Characterization of biofilm matrix, degradation by DNase treatment and evidence of capsule downregulation in Streptococcus pneumoniae clinical isolates. BMC Microbiol. 2008, 8, 173. [CrossRef]

63. Niazi, S.A.; Clark, D.; Do, T.; Gilbert, S.C.; Foschi, F.; Mannocci, F.; Beighton, D. The effectiveness of enzymic irrigation in removing a nutrient-stressed endodontic multispecies biofilm. Int. Endod. J. 2014, 47, 756-768. [CrossRef]

64. Niazi, S.A.; Al-Ali, W.M.; Patel, S.; Foschi, F.; Mannocci, F. Synergistic effect of 2\% chlorhexidine combined with proteolytic enzymes on biofilm disruption and killing. Int. Endod. J. 2015, 48, 1157-1167. [CrossRef]

65. Ali Mohammed, M.M.; Nerland, A.H.; Al-Haroni, M.; Bakken, V. Characterization of extracellular polymeric matrix, and treatment of Fusobacterium nucleatum and Porphyromonas gingivalis biofilms with DNase I and proteinase K. J. Oral Microbiol. 2013, 5, 20015. [CrossRef]

66. Lim, E.S.; Koo, O.K.; Kim, M.J.; Kim, J.S. Bio-enzymes for inhibition and elimination of Escherichia coli O157:H7 biofilm and their synergistic effect with sodium hypochlorite. Sci. Rep. 2019, 9, 9920. [CrossRef]

67. George, J.; Halami, P.M. Presence of extracellular DNA \& protein in biofilm formation by gentamicin-resistant Lactobacillus plantarum. Indian J. Med. Res. 2019, 149, 257-262. [CrossRef]

(C) 2020 by the authors. Licensee MDPI, Basel, Switzerland. This article is an open access article distributed under the terms and conditions of the Creative Commons Attribution (CC BY) license (http://creativecommons.org/licenses/by/4.0/). 